\title{
Characteristics of ash, maple, yew/ juniper, and willow pollen seasons in the air of Kielce in 2021 in correlation with weather conditions
}

\author{
Joanna Ślusarczyk', Anna Kopacz-Bednarska², Joanna Posłowska' \\ ${ }^{1}$ Department of Environmental Biology, Institute of Biology, Jan Kochanowski University in Kielce \\ Head of the Department: Joanna Czerwik-Marcinkowska, PhD, Assoc. Prof. \\ ${ }^{2}$ Department of Medical Biology, Institute of Biology, Jan Kochanowski University in Kielce \\ Head of the Department: Michał Arabski, PhD, Assoc. Prof.
}

\begin{abstract}
:
The paper presents the course of ash, maple, yew, juniper, and willow pollen seasons in the city of Kielce in 2021. These are the first published aerobiological studies of these species from this city. The investigations were carried out with the volumetric method using a Lanzoni apparatus. The pollen season was determined with the method of $98 \%$ of the annual pollen grain sum. In Kielce, the highest concentrations of ash pollen (85 grains $/ \mathrm{m}^{3}$ of air) were recorded on April 21 $1^{\text {st }}$, maple pollen $\left(71 \mathrm{grains} / \mathrm{m}^{3}\right)$ on April $28^{\text {th }}$, yew and juniper pollen (120 grains $\left./ \mathrm{m}^{3}\right)$ on April $1^{\text {st }}$, and willow pollen $\left(66 \mathrm{grains} / \mathrm{m}^{3}\right)$ on May $12^{\text {th }}$. The parameters of the pollen season were analyzed statistically with reference to the selected meteorological parameters.
\end{abstract}

Key words: pollen grains, pollen count, ash (Fraxinus), maple (Acer), yew and juniper (Taxus and Juniperus), willow (Salix), 2021

\section{Introduction}

Air-borne pollen grains and fungal spores cause seasonal inhalation allergy, which is most often an allergic reaction to pollen. Its symptoms vary widely depending on the type of allergen and the type of allergy and may include allergic rhinitis, bronchial asthma, skin lesions, gastrointestinal reactions, and conjunctivitis [1]. The development of allergy symptoms depends on the presence of allergenic substances in the air, and their severity correlates with the concentration of allergens [2]. These health problems are diagnosed in approximately $30 \%$ of Europeans, including the population of Poland [3-5]. Protein substances contained in pollen grains of anemophilous plants producing large amounts of pollen have especially high aller- genic potential. In the conditions of our country, pollen allergy most often affects patients during the period of increased release of grass pollen, i.e. usually from the second half of May to the end of July. However, increasing numbers of allergy cases are caused by pollen of such trees as hazel, alder, birch, ash, maple, yew, juniper, and willow. Additionally, pollen of these taxa is increasingly being indicated in cross-reactions with pollen grains of other plant species leading to an allergic reaction. In the present study, we analyzed taxa that are classified as moderately allergenic. Nevertheless, given the aforementioned interactions, they are progressively attracting allergists attention. The investigations were also focused on the impact of weather 
conditions on the concentration of ash, maple, yew/ juniper, and willow pollen grains in the air of Kielce in 2021. This is the first report on the characteristics of pollen seasons in Kielce.

The common ash (Fraxinus excelsior L.) is a representative of the family Oleaceae. The species is found in western and central Europe. In Poland, it grows in lowlands and lower parts of the mountains. The tree is characterized by rapid growth; hence, it is often planted near roads, in parks, and around buildings. Several other species of the genus Fraxinus are cultivated as well, e.g. Pennsylvania ash (Fraxinus pennsylvanica) and manna ash (Fraxinus ornus) [6]. Ash flowers are inconspicuous, brownish, and have no perianth. One tree can have male, female, and prefect flowers. The male flower has two red-brown stamens. The anemophilous flowers are gathered in short panicles. They usually flower in April-May, and their fruits ripen in October [7]. The common ash is a very common species in Poland, but there are large differences in the content of its pollen in the aeroplankton of Polish cities [8, 9]. The pollen grains are tri- or tetracolpate in the polar position, rounded, and slightly three- or four-angled. Their average size is $19 \times 22 \mu \mathrm{m}$. The colpi are long and narrow (fig. 1A). The reticulate exine has different-sized meshes. Ash pollen has moderate allergenic potential. Nevertheless, it may cross-react with pollen from privet and olive trees [10].

The maple (Acer sp.) represents the family Sapindaceae growing in the temperate climate zone. Maple trees are also widespread in Poland. The Norway maple (Acer platanoides L.), sycamore maple (Acer pseudoplatanus L.), and field maple (Acer campestre L.) can be found in natural sites. The ashleaf maple Acer negundo L. is regarded as an invasive species in Poland [11]. It is probably the source of substantial amounts of airborne pollen grains [12]. Maple trees grow in deciduous forests; they are also planted along roadsides and in parks. They flower in April and May. Their yellow-green bisexual and unisexual flowers are produced before or simultaneously with leaf development. They form erect or pendulous inflorescences. The genus comprises entomophilous or secondarily anemophilous species, e.g. the ash-leaf maple (Acer negundo L.). Maple pollen grains are medium-sized, usually reaching a size of $28 \times 32 \mu \mathrm{m}$. They have three wide colpi. They are roundish in the equatorial position and slightly flattened at the poles. In the polar position, they have a triangular outline (fig. 1B). The exine is slightly striated. The pollen has slight or moderate allergenic potential [10].
The yew is a representative of the family Taxaceae. In Poland, it is represented by one native species, i.e. the common yew (Taxus baccata L.), which is protected in natural localities. Its varieties are often planted as ornamental trees in parks and gardens. It flowers between March and May. The plant is dioecious and anemophilous. Numerous yellow staminate flowers develop on the lower sides of branches. Female flowers are borne singly in leaf axils. Yew pollen grains are spherical and apertureless (fig. 1C). They have a size of $24 \times 25 \mu \mathrm{m}$. Their thin exine ruptures easily, which results in leakage of the cytoplasm. The exine surface has evenly distributed granular structures. The intine has varying thickness; therefore, the cytoplasm has a "stellar" form [10].

The common juniper (Juniperus communis L.) is a species from the family Cupressaceae. It is a dioecious shrub with a columnar or conical habit. Its height ranges from 2 to 10 meters. The prickly bluegreen needles of this evergreen shrub are approximately $1.5 \mathrm{~cm}$ long and are arranged in whorls of three. The male inflorescences are yellowish and less than $5 \mathrm{~mm}$ long. The female inflorescences are greenish. Juniper has dark blue-red berries with a waxy coating; they are edible in small amounts. The species has a wide occurrence range. It grows in meadows that are poor in organic compounds, heaths, dunes, and light coniferous forests. There are also numerous garden varieties [7]. The plant usually flowers between April and May.

Yew pollen grains are difficult to distinguish from juniper pollen using a standard light microscope; therefore, many authors present collective concentrations of pollen from these taxa, likewise in this study. Yew shrubs flower earlier than juniper; hence, based on phenological observations, it is possible to distinguish a yew-dominated early phase, a yew-dominated juniper phase, and a juniper-dominated late phase [13]. Juniper and yew pollen allergens are a documented cause of allergic diseases in European and Asian countries [14-16].

The willow (Salix sp.) is distributed across Europe. In Poland, it most often grows in the northeastern part of the country. Willows can be found in forest margins, clearings, and lowlands [17]. The genus Salix belongs to the family Salicaceae. Approximately 400 species of willow occur in areas with cool and temperate climate, and 26 various hybrid species grow Poland. These are most often shrubs, but some species have a tree habit [17]. Willows are heliophilic plants. They prefer moist areas but can also grow in dry soils (e.g. Salix purpurea L.). Their dioecious flowers with male and female specimens arranged sep- 
arately on different trees develop before leaves. Male flowers form $3.5-5 \mathrm{~cm}$ long ovoid catkins, and female flowers are narrower and greenish. The melliferous willow flowers provide bees with pollen and nectar in spring. Willows usually flower from March to May [7]. All willow species are entomophilous, but large amounts of pollen are transported by the wind. Willow pollen grains are tricolpate, roundish, or slightly oval (fig. 1D). With their size of $15-16 \mu \mathrm{m}$, they are classified as small grains. The exine has a reticulate structure with smaller meshes near the colpi and poles [10].

The proteins contained in willow pollen grains have low allergenic potential. It is believed, however, that willow pollen may aggravate the symptoms of asthma, allergic rhinitis, and conjunctivitis, especially in subjects that are allergic to pollen of other trees, especially birch [18]. Cross-reactions between the pollen of willow and poplar, which represent the same family, are the main cause of intensification of seasonal allergic symptoms [10].
(Taxus/Juniperus), and willow (Salix) in Kielce in 2021 with reference to selected weather conditions.

\section{Material and methods}

The analysis of pollen seasons of the selected allergenic taxa was carried out in Kielce with the volumetric method. The concentration of pollen grains was measured using the Lanzoni VPPS 2000 apparatus. The device was placed on a terrace of the building of the Institute of Biology, Jan Kochanowski University in Kielce, at an altitude of $18 \mathrm{~m}$ above ground level. In 2021, the apparatus was operated in a continuous volumetric mode, and the pollen sampling tape was replaced once a week. After staining with alkaline fuchsin, the microscope slides were analyzed using a Nikon optical microscope $(\times 300)$. Previously prepared standard slides were used for the morphological pollen analysis. The aeropalynological measurements were made to determine the daily number of pollen

Figure 1. Pollen grains from the trees analyzed in spring. A. Ash (Fraxinus sp.). B. Maple (Acer sp.). C. Juniper (Juniperus sp.). D. Willow (Salix sp.). Magnification $400 \times$, bars $-10 \mu \mathrm{m}$.

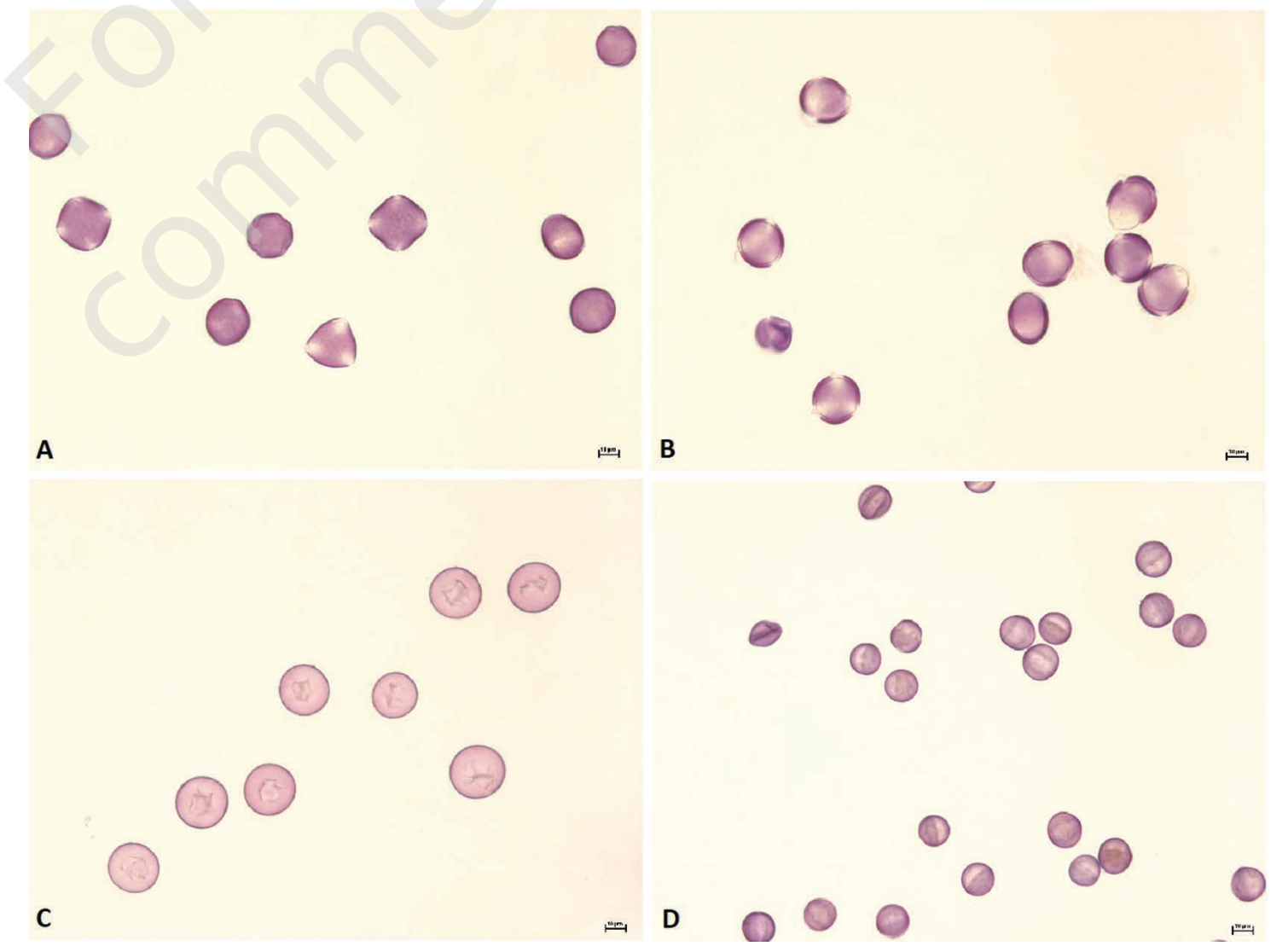

Aim

The aim of the study was to analyze the pollen season of ash (Fraxinus), maple (Acer), yew/juniper grains of the analyzed plant taxa in $1 \mathrm{~m}^{3}$ of air. Based on literature data, the length of the pollen season was determined with the $98 \%$ method, where days with 
$1 \%$ and $99 \%$ of the annual sum of pollen grains were regarded as the beginning and the end of the season, respectively [19]. The pollen seasons of the analyzed plants were compared with some meteorological parameters for Kielce, i.e. maximum air temperature $\left({ }^{\circ} \mathrm{C}\right)$, average wind speed $(\mathrm{m} / \mathrm{s})$, average air humidity $(\%)$, and daily precipitation sum $(\mathrm{mm})$. The data for the Kielce-Suków station were provided by the Institute of Meteorology and Water Management of the National Research Institute [20]. The impact of the weather conditions on the pollen season was assessed by calculation of Pearson's linear correlation. Statistical analyses were performed using the STATISTICA 10.0 software (Statsoft, Poland) at the $\mathrm{p}<0.05$ level confirming statistical significance of differences. The photographs of the pollen grains were taken with the Eclipse 80i optical microscope (Nikon, Poland).

\section{Results and discussion}

The basic parameters of the pollen seasons of the examined plant taxa are presented in table 1, and the dynamics of the seasons is presented in figures 2-5. In 2021, the first pollen grains of ash (Fraxinus) were recorded in the atmosphere of Kielce during the first ten days of April. The pollen season determined with the $98 \%$ method lasted for 24 days until May $13^{\text {th }}$. The highest daily concentration of Fraxinus pollen, i.e. 85 grains $/ \mathrm{m}^{3}$, was noted on April $21^{\text {st }}$. The seasonal pollen index (SPI) was 574. Throughout the ash pollen season, there were 8 days with values exceeding 20 grains $/ \mathrm{m}^{3}$ and only 4 days with concentrations exceeding 50 grains $/ \mathrm{m}^{3}$ (tab. 1, fig. 2).

The maple (Acer) pollen season began on April $22^{\text {nd }}$ and ended on May $20^{\text {th }}, 2021$. The maximum concentration of Acer pollen (71 grains $/ \mathrm{m}^{3}$ ) was recorded

Table 1. Characteristics of Fraxinus, Acer, Taxus/Juniperus, and Salix pollen seasons in the atmospheric air of Kielce in 2021.

\begin{tabular}{|c|c|c|c|c|c|}
\hline \multicolumn{2}{|l|}{ Taxons } & Fraxinus & Acer & Taxus and Juniperus & Salix \\
\hline \multicolumn{2}{|c|}{$\begin{array}{l}\text { Duration of pollen season } \\
\text { Length of pollen season }\end{array}$} & $\begin{array}{l}20.04-13.05 \\
24 \text { days }\end{array}$ & $\begin{array}{l}22.04-20.05 \\
29 \text { days }\end{array}$ & $\begin{array}{l}25.03-8.06 \\
76 \text { days }\end{array}$ & $\begin{array}{l}1.04-4.06 \\
65 \text { days }\end{array}$ \\
\hline \multicolumn{2}{|l|}{$\begin{array}{l}\text { Peak value }\left[\mathrm{grains} / \mathrm{m}^{3} \text { ] }\right. \\
\text { Peak date }\end{array}$} & $\begin{array}{l}85 \\
21.04\end{array}$ & $\begin{array}{l}71 \\
28.04\end{array}$ & $\begin{array}{l}120 \\
1.04\end{array}$ & $\begin{array}{l}66 \\
12.05\end{array}$ \\
\hline \multicolumn{2}{|c|}{ Seasonal pollen index (SPI) } & 574 & 489 & 1055 & 890 \\
\hline \multirow{4}{*}{$\begin{array}{l}\text { Number of days with } \\
\text { concentration above } \\
\text { threshold }\end{array}$} & days $\geq 0$ grains $/ \mathrm{m}^{3}$ & 31 & 37 & 80 & 73 \\
\hline & days $\geq 20$ grains $/ \mathrm{m}^{3}$ & 8 & 7 & 15 & 13 \\
\hline & days $\geq 50$ grains $/ \mathrm{m}^{3}$ & 4 & 2 & 5 & 3 \\
\hline & days $\geq 100$ grains $/ \mathrm{m}^{3}$ & 0 & 0 & 2 & 0 \\
\hline
\end{tabular}

Figure 2. Fraxinus pollen count in Kielce in 2021 in relation to selected meteorological factors.

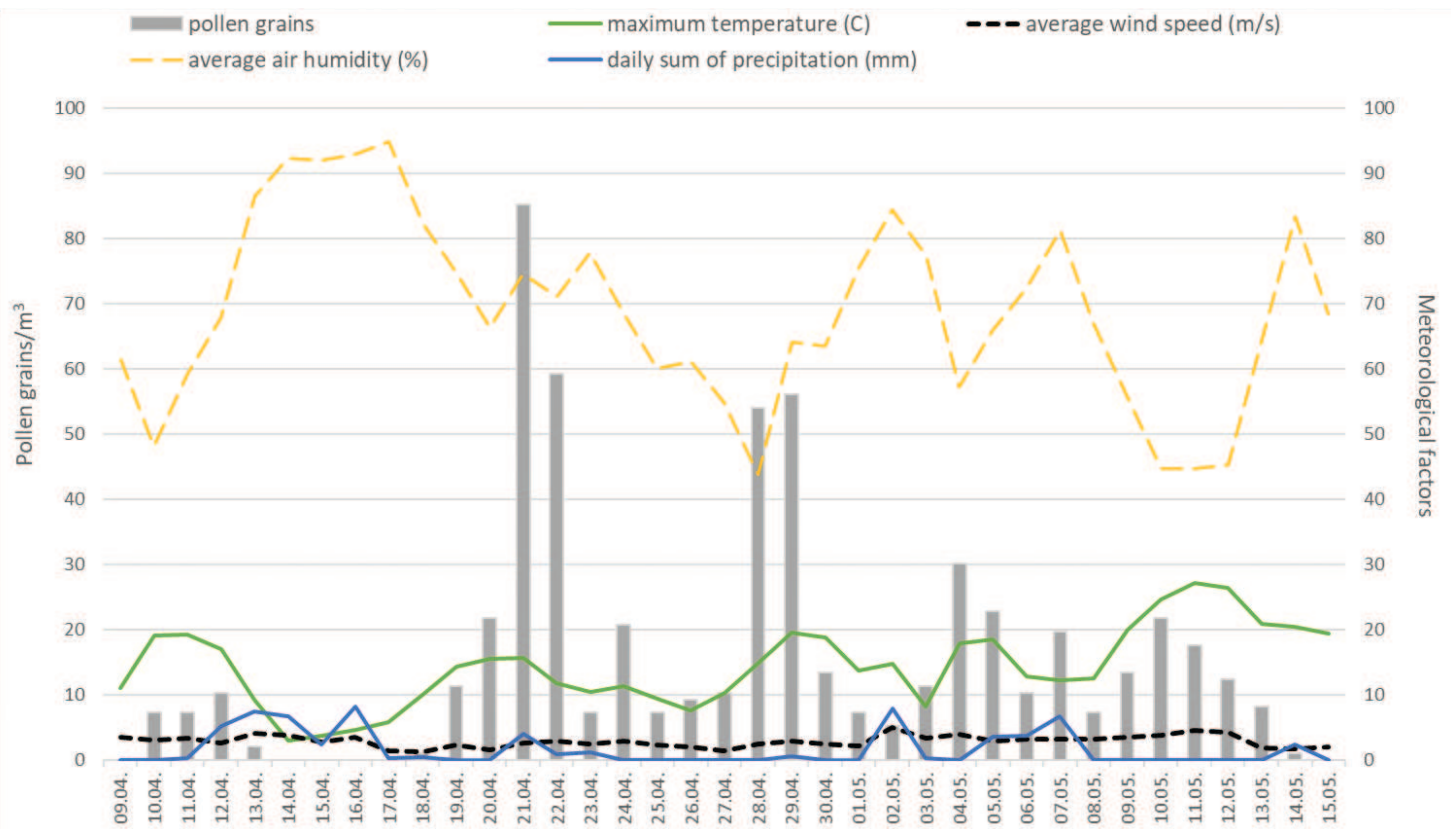


on April $28^{\text {th }}$, with the annual sum of 489 . Throughout the maple pollen season, the threshold values of 20 grains $/ \mathrm{m}^{3}$ and 50 grains $/ \mathrm{m}^{3}$ were exceeded on 7 and 2 days, respectively (tab. 1, fig. 3 ).

The pollen season of yew and juniper (Taxus and Juniperus) determined with the $98 \%$ method started on March $25^{\text {th }}$ and lasted for 76 days. The highest concentration of these pollen grains, i.e. 120 grains $/ \mathrm{m}^{3}$, was recorded on April $1^{\text {st }}$. The annual sum of Taxus and Juniperus pollen was 1055. In 2021, there were 15 days with the concentration of yew and juniper pollen grains exceeding 20 grains $/ \mathrm{m}^{3}$ in the air of Kielce, 5 days with a concentration higher than 50 grains $/ \mathrm{m}^{3}$, and 2 days with a concentration above 100 grains $/ \mathrm{m}^{3}$ (tab. 1, fig. 4).

The first willow (Salix) pollen grains were recorded in the air of Kielce on March 20 ${ }^{\text {th }}, 2021$ and persisted until June $15^{\text {th }}$. The compact Salix pollen season lasted for 65 days from April $1^{\text {st }}$ to June $4^{\text {th }}$, with an annual sum of 890 pollen grains. The willow pollen peak (66 grains $\left./ \mathrm{m}^{3}\right)$ was observed on May $12^{\text {th }}$. During the Salix pollen season, there were 13 days

Figure 3. Acer pollen count in Kielce in 2021 in relation to selected meteorological factors.

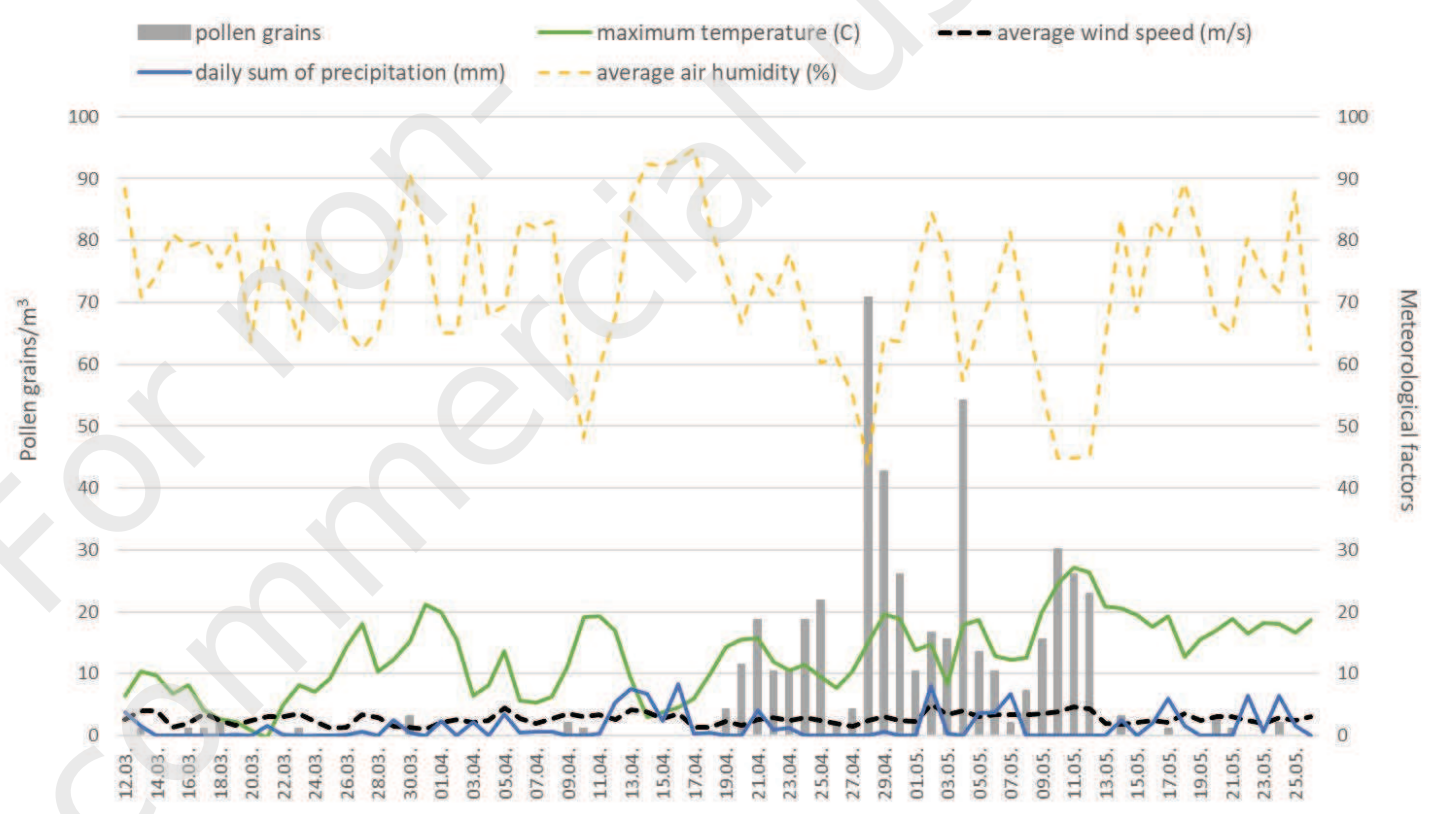

Figure 4. Taxus/Juniperus pollen count in Kielce in 2021 in relation to selected meteorological factors.

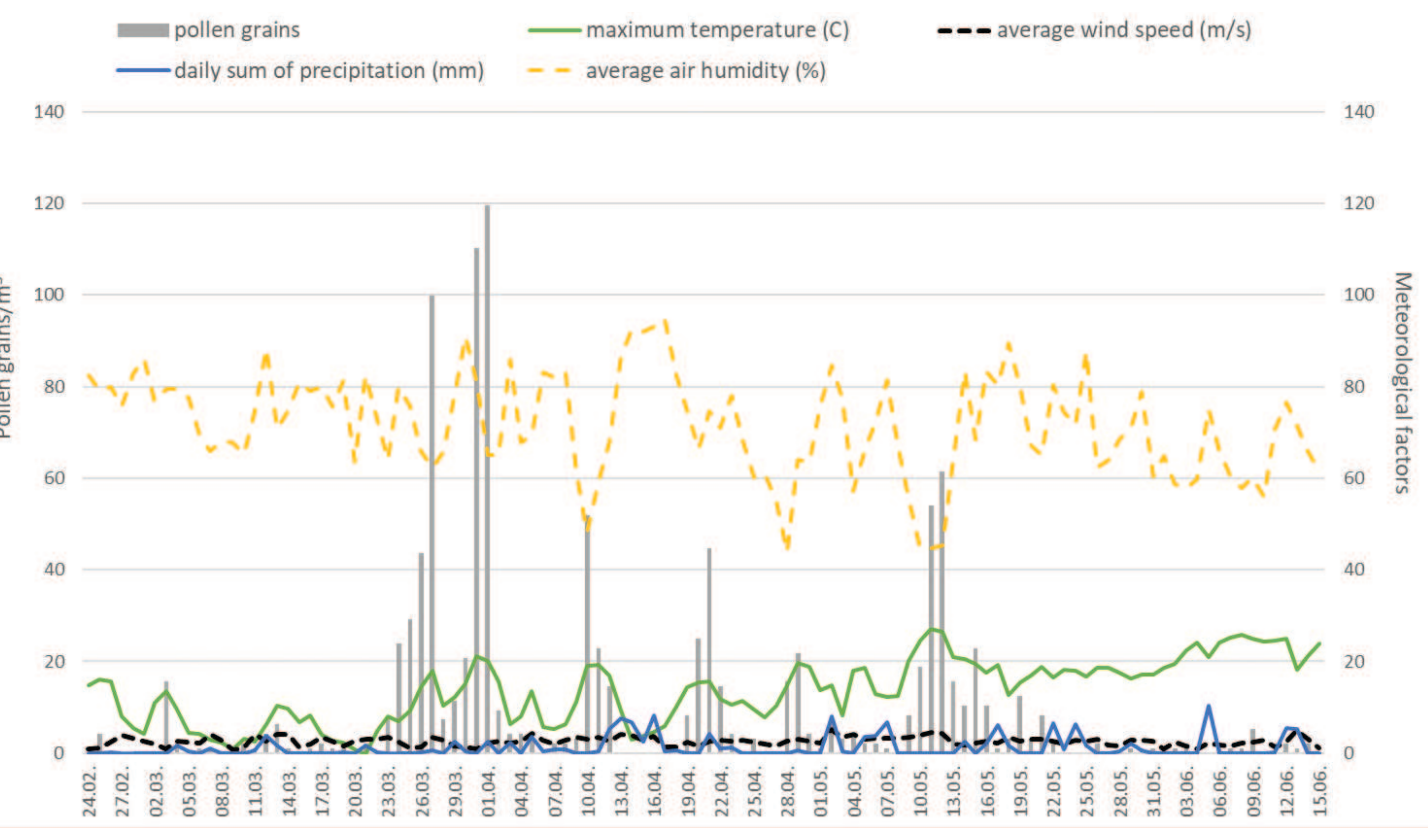


with a concentration exceeding the threshold value of 20 grains $/ \mathrm{m}^{3}$ and 3 days with a concentration above 50 grains $/ \mathrm{m}^{3}$. No values exceeding 100 grains $/ \mathrm{m}^{3}$ were recorded in the air of Kielce in 2021 (tab. 1, fig. 5). wind speed $(r=0.31)$, and air humidity $(r=-0.41)$ was confirmed for Salix pollen. Pearson's correlation revealed a clear relationship between Taxus and $J u$ niperus pollen counts and the maximum temperature

Figure 5. Salix pollen count in Kielce in 2021 in relation to selected meteorological factors.

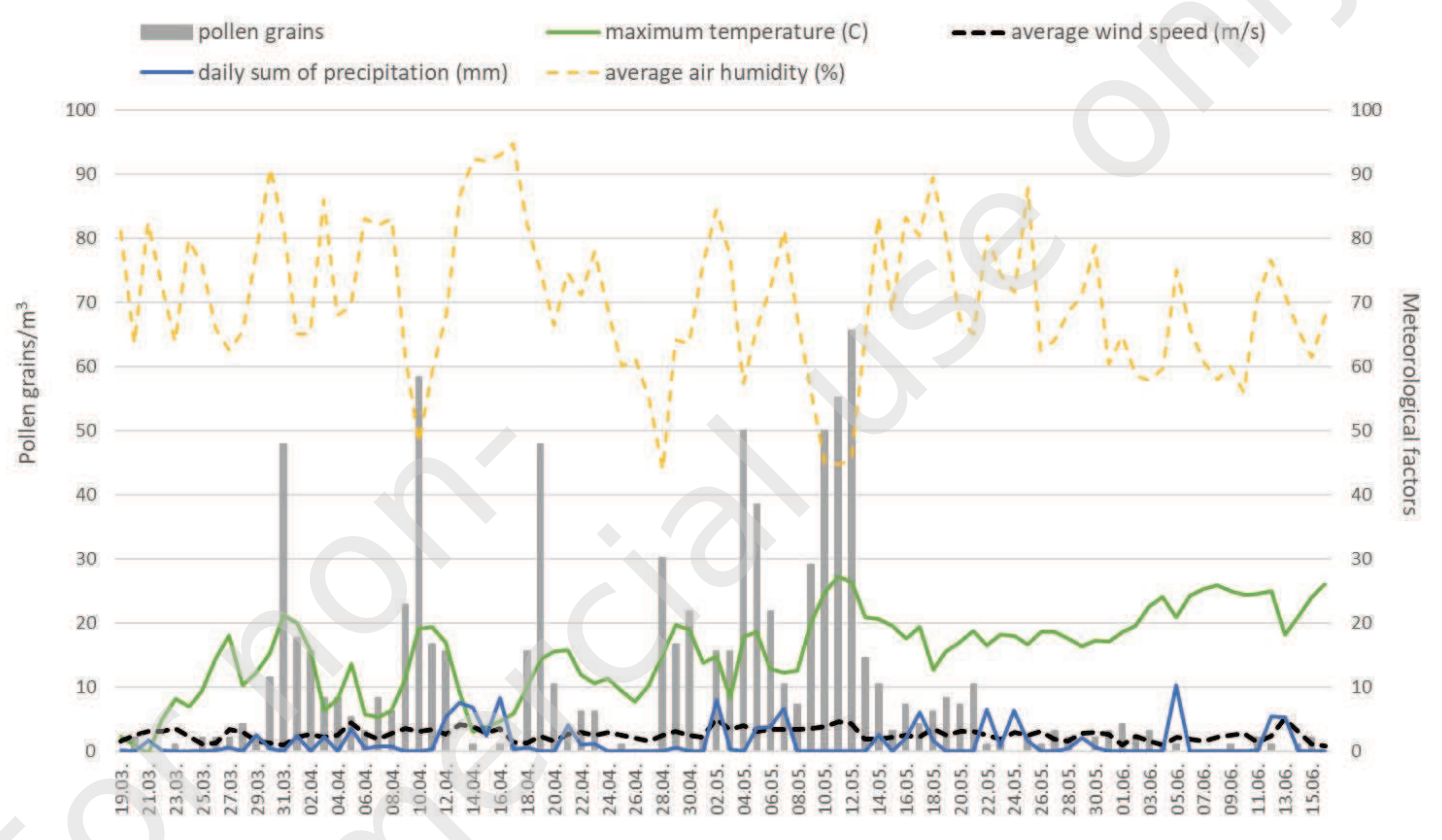

Table 2. Results of Pearson's $r$ correlation between the total count of pollen grains and the selected meteorological factors $(* p<0.05 ; * * p<0.01 ; * * * p<0.001)$.

\begin{tabular}{|c|c|c|c|c|}
\hline \multirow{2}{*}{ Meteorological factors } & \multicolumn{4}{|c|}{ Total pollen grains } \\
\hline & Fraxinus & Acer & Taxus and Juniperus & Salix \\
\hline Maximum temperature & 0.24 & $0.34^{\star *}$ & $0.29^{* *}$ & $0.28^{\star *}$ \\
\hline Average wind speed & 0.02 & $0.26^{*}$ & -0.00 & $0.31^{* *}$ \\
\hline Average air humidity & -0.29 & $-0.52^{* * *}$ & $-0.23^{\star}$ & $-0.41^{\star \star *}$ \\
\hline Daily sum of precipitation & -0.08 & -0.14 & -0.07 & -0.15 \\
\hline
\end{tabular}

The concentration of pollen grains in the air depends on e.g. meteorological conditions [10, 21]. The results of Pearson's correlation between the total concentration of pollen grains of the analyzed taxa and the selected weather conditions are shown in table 2. As revealed by the statistical analysis, the number of Fraxinus pollen grains was not significantly correlated with the meteorological conditions. In turn, a strong correlation was observed between the meteorological factors and the amounts of maple pollen. A statistically significant positive correlation was found between the number of Acer pollen grains and the average wind speed $(r=0.26)$ and the maximum air temperature $(r=0.34)$. The pollen concentration was negatively correlated with the average air humidity $(r=-0.52)$. A similar relationship between temperature $(r=0.28)$, $(r=0.29)$ and air humidity $(r=-0.23)$. The analyses revealed no correlation between the concentration of the analyzed pollen grains in the Kielce aeroplankton and the precipitation sum.

The present results indicate differences in the obtained values in comparison with long-term data from even closely located cities [9, 12, 13, 22]. The beginning of the season and the pollen release intensity exhibited by the analyzed taxa depend on weather conditions, mainly air temperature in winter and early spring. The species composition of the flora characteristic of a given area can exert a certain impact as well. Regional differences in pollen release dates and concentrations of pollen of the studied taxa have been confirmed in many previous aeropalynological studies $[9,12,13,22]$. The diversity of the values presented 
in this study indicates that the process of qualification for immunotherapy should be based on up-to-date data. Weather anomalies are being observed with increasing frequency; hence, airborne pollen may be present at different terms than expected $[23,24]$. Therefore, it is extremely important to conduct regional biomonitoring.

The results of the present study confirm the need to follow the most current data on concentrations of aeroallergens characteristic for a given region, as they have a significant impact on the effectiveness of the treatment of allergic diseases.

\section{Conclusion}

Among the plant taxa studied, the pollen of yew and juniper (Taxus and Juniperus) was the first to appear in the atmosphere of Kielce.

Taxus/Juniperus and Salix pollen grains persisted in the bioaeroplankton for the longest time. Fraxinus was characterized by the shortest pollen season, whereas the longest pollen release period was recorded for Taxus and Juniperus.

The highest annual sum of pollen grains (SPI) and the highest maximum concentration were determined in the case of Taxus and Juniperus. The lowest SPI value was recorded for the maple (Acer) pollen, whereas the willow (Salix) was characterized by the lowest maximum concentration of pollen grains.

The statistical analysis revealed a statistically significant positive correlation between the number of pollen grains of maple, willow, yew, and juniper with the average wind speed and maximum air temperature and a negative correlation with the average air humidity.

\section{References}

1. Rapiejko P, Lipiec A. Pyłek roślin jako aeroalergen. Terapia. 2001; 3: 3-9.

2. Weryszko-Chmielewska E, Piotrowska-Weryszko K, Sulborska A et al. Zanieczyszczenia biologiczne i pytowe w powietrzu atmosferycznym zagrażajace zdrowiu człowieka. Alergoprofil. 2015; 11(3): 23-7.

3. Leynaert B, Neukrich C, Kony $S$ et al. Association between asthma and rhinitis according to atopic sensitization in a population-based study. J Allergy Clin Immunol. 2004; 1: 86-93. http://doi.org/10.1016/j.jaci.2003.10.010.

4. Bousquet J, Khaltaev N, Cruz AA et al. Allergic Rhinitis and Its Impact on Asthma (ARIA 2008) Allergy. 2008; 68(86): 8-160. http://doi.org/10.1111/j.1398-9995.2007.01620.x.
5. Rapiejko P, Stankiewicz W, Szczygielski K et al. Progowe stężenie pytku roślin niezbędne do wywołania objawów alergicznych. Otolar Pol. 2007; (61)4: 591-4.

6. Szweykowscy AJ. Stownik botaniczny. Wiedza Powszechna, Warszawa 2003.

7. Bachofer M, Mayer J. Drzewa. MULTICO Oficyna Wydawnicza, Warszawa 2007.

8. Weryszko-Chmielewska E, Piotrowska-Weryszko K, Rapiejko $P$ et al. Zawartość pytku jesionu w powietrzu wybranych miast Polski w 2014 r. Alergoprofil. 2014; 10(3): 36-41.

9. Puc M, Kotrych D, Lipiec A et al. Ash pollen season in Poland in 2019. Alergoprofil. 2019; 15(4): 17-22. http://doi. org/10.24292/01.AP.154181219.

10. Weryszko-Chmielewska E. Aerobiologia. Wydawnictwo Akademii Rolniczej w Lublinie, Lublin 2007.

11. Dajdok Z, Pawlaczyk P. Inwazyjne gatunki roślin ekosystemów mokradlowych Polski. Wydawnictwo Klubu Przyrodników, Świebodzin 2009.

12. Dąbrowska-Zapart K, Chtopek K, Świdnicka-Siergiejko $A$ et al. Maple pollen season in selected cities of Poland in 2018. Alergoprofil. 2018; 14(3): 82-6. http://doi. org/10.24292/01.AP.290618.

13. Dąbrowska-Zapart K, Chtopek K, Puc M et al. Yew and juniper pollen season in selected cities of Poland in 2020. Alergoprofil. 2020; 16(4): 10-4. http://doi.org/10.24292/01. AP.164311220.5.

14. Hrabina M, Purohit A, Oster JP et al. Standardization of on Ash (Fraxinus excelsior) pollen allergen extract. Int. Arch. Allergy Immunol. 2007; 142: 11-8. http://doi.org/10.1159/000095994.

15. Kimura Y, Kamamoto M, Maeda M et al. Occurrence of Lewis a epitope in $N$-glycans of a glycoallergen, Jun a 1, from mountain cedar (Juniperus ashei) pollen. Biosci Biotechnol Biochem. 2005; 69(1): 137-44.

16. Panzani R, Yasueda H, Shimizu T et al. Cross-reactivity between the pollens of Cupressus sempervirens (common cypress) and of Cryptomeria japonica (Japanese cedar). Ann Allergy. 1986; 57(1): 26-30. http://doi.org/10.1016/S10811206(10)62746-9.

17. Seneta W, Dolatowski J. Dendrologia. PWN, Warszawa 2008.

18. Guneser S, Atici A, Cengizler I et al. Inhalant allergens: as a cause of respiratory allergy in east Mediterranean area, Turkey. Allergol Immunopathol. 1996; 24(3): 116-9.

19. Emberlin J, Savage M, Woodman R. Annual variations in the concentrations of Betula pollen in the London area 1961-1990. Grana. 1993; 32: 359-63. http://doi. org/10.1080/00173139309428965.

20. Instytut Meteorologii i Gospodarki Wodnej - Państwowy Instytut Badawczy. www.meteomodel.pl (access: 27.07.2021).

21. Piotrowicz K, Myszkowska D. Zmiany klimatu i ich wptyw na sezony pyłkowe wybranych roślin alergennych $w$ Polsce. In: Kolendowicz L, Bednorz E, Tomczyk A (ed). Zmienność klima- 
tu Polski i Europy oraz jej cyrkulacyjne uwarunkowania. Bogucki Wydawnictwo Naukowe, Poznań 2019: 173-90.

22. Myszkowska D, Ziemianin M, Czarnobilska E et al. Analiza sezonów pytkowych wierzby $w$ wybranych miastach Polski w 2014 r. Alergoprofil. 2014; 10(3): 25-30.

23. Rapiejko P. Aerobiologia medyczna. Alerg Astma Immun. 2006; 11(2): 76-82.

24. Majkowska-Wojciechowska B. Pytek roślin i alergeny sezonowe w Polsce. Alerg Astma Immun. 2016; 21(1): 5-15.

ORCID

J. Ślusarczyk - ID - http://orcid.org/0000-0001-8022-3244

A. Kopacz-Bednarska - ID - http://orcid.org/0000-0003-0664-1450

J. Posłowska - ID - http://orcid.org/0000-0002-6310-0688

Authors' contributions:

J. Ślusarczyk: 45\%; A. Kopacz-Bednarska: 45\%; J. Posłowska: 10\%. Conflict of interests:

The authors declare that they have no competing interests.
Financial support:

This study was partially funded by research funds for 2021 as a research project SUPB. RN.21.247

Ethics:

The contents presented in this paper are compatible with the rules the Declaration of Helsinki, EU directives and standardized requirements for medical journals. Research in Kielce.

Copyright: (c) Medical Education sp. z 0.0. This is an Open Access article distributed under the terms of the Attribution-NonCommercial 4.0 International (CC BY-NC 4.0). License (https://creativecommons.org/licenses/by-nc/4.0/), allowing third parties to copy and redistribute the material in any medium or format and to remix, transform, and build upon the material, provided the original work is properly cited and states its license.

\section{Correspondence:}

Joanna Ślusarczyk, PhD

Department of Environmental Biology, Institute of Biology, Jan Kochanowski University in Kielce 25-406 Kielce, ul. Uniwersytecka 7

phone: 413496318

e-mail: joanna.slusarczyk@ujk.edu.pl 